\title{
A política externa das últimas décadas do Império Brasileiro (1870-1889)
}

Daniel Rei Coronato ${ }^{1}$

\section{Resumo}

Este artigo tem como eixo central o estudo das relações exteriores do Império Brasileiro, durante o período de 1870-1889. A proposta é contribuir com as pesquisas históricas das relações internacionais das Américas, fundamentando-se no objetivo de dar inteligibilidade às linhas gerais da política externa do Brasil, em meio ao processo de declínio do regime monárquico.

Palavras-Chave: Brasil, História da Política Externa Brasileira, Império Brasileiro

\begin{abstract}
The main axis of this article is the study of Brazilian Empire foreign relations during the period 1870-1889. The proposal is to contribute to the historical researches of Americas international relations, having as objective understanding the general outlines of foreign policy in the process of Brazilian Monarchy downturn.
\end{abstract}

Keywords: Brazil, Brazilian Foreign Policy History, Brazilian Empire

Artigo recebido em: 15/05/2013

Artigo aprovado em: 19/08/2013

\section{Introdução}

Este estudo se propõe a contribuir para o debate histórico e político brasileiro, tendo como eixo central o estudo das relações exteriores do Império Brasileiro, durante o período de 1870-1889, fundamentando-se no objetivo de entender as suas linhas gerais, em meio ao processo de declínio do regime monárquico. A grande questão a ser respondida é: Afinal, como se comportou a política externa do Brasil durante os últimos anos de regime monárquico? Quais foram os seus eixos de atuação e seu sentido geral? Qual foi o impacto da sua inserção no seu entorno geográfico, especialmente na região do Prata e nas iniciativas de integração americanas?

Inicialmente, torna-se importante ressaltar a grande lacuna existente nos estudos da história da política externa brasileira, referente aos últimos anos do Império. A explicação para essa

\footnotetext{
${ }^{1}$ Mestre em Ciências Sociais pela Pontifícia Universidade Católica de São Paulo. Docente da graduação em Relações Internacionais do SENAC-SP (Brasil) e membro pesquisador do NACI (Núcleo de Análise de Conjuntura Internacional) da PUC-SP. Email: daniel_coronato@hotmail.com
}

Revista Eletrônica da ANPHLAC, ISSN 1679-1061, n.15, p. 113-131, jul./dez. 2013.

http://revista.anphlac.org.br/ 
realidade parece ser óbvia, já que se conveniou olhar para o processo de erosão do regime monárquico brasileiro, como sendo regido por uma supremacia dos assuntos internos sobre as problemáticas internacionais. Todas as crises institucionais e políticas dos anos finais do reinado de D. Pedro II parecem comprovar essa tese, especialmente pelo desenrolar dos eventos que culminariam em 15 de Novembro de 1889, com a Proclamação da República.

Apesar dessa preponderância da esfera interna, e até o rebaixamento dos assuntos internacionais a um segundo plano, especialmente se contrastarmos com a importância dada a eles durante praticamente toda a década de 60 do século XIX, o período é rico em aspectos elementares do processo de constituição histórica da política externa do Brasil. Nele, são apresentados processos que agem como um grande catalizador de movimentos internos, sistêmicos e, especialmente, nas relações múltiplas de poder, que derivaram em certas peculiaridades na execução e entendimento do interesse nacional, principalmente, por guardar o momento que levaria à ruptura institucional e à posterior Proclamação da República.

Dentro desse contexto histórico, o final da Guerra do Paraguai simbolizaria um paradoxo de diversas formas. $\mathrm{O}$ ano de 1870 representou o período áureo do Império na sua capacidade de projeção internacional. Apesar da sua força incontestável no âmbito regional, a realidade doméstica já começava a dar sinais de uma progressiva deterioração do equilíbrio político institucional e do regime monárquico. O fenômeno político que levou ao fim do Segundo Reinado, em 1889, derivou dos dois grandes problemas que o Império foi incapaz de solucionar de forma satisfatória: a abolição da escravatura e o novo papel dos militares no momento seguinte ao final do conflito (CALMON, 2002, p. 237-238). Além disso, problemas com a Igreja e a pressão das oligarquias regionais, alocadas ou não em partidos (CHACON, 1981, p. 53), colocariam em xeque as bases de sustentação da monarquia. Em suma: o Império experimentaria mudanças e transformações profundas em um período de duas décadas.

A hipótese deste artigo, em consonância com a tese defendida na obra História da política exterior do Brasil (CERVO; BUENO, 2008), ainda carente de um estudo sistematizado, é que, ao final do Império, duas grandes tendências interagiam. A primeira delas seria uma distensão externa, especialmente vinculada pelos eventos no subsistema do Prata; e a segunda seria um universalismo externo, especialmente nas questões econômicas e de prestígio. Aparentemente contraditórias, as duas tendências orientavam o sentido da política externa naqueles anos.

Segundo a hipótese defendida por Cervo e Bueno (CERVO; BUENO, 2008), a distensão teria sido desejada, administrada e planejada pelo Estado por inúmeros fatores, dentre eles: primeiro - a Guerra do Paraguai desviou recursos e provocou grave crise interna, ocasionando grandes repercussões na estrutura das instituições imperiais; segundo - os velhos conflitos com a Inglaterra,

Revista Eletrônica da ANPHLAC, ISSN 1679-1061, n.15, p. 113-131, jul./dez. 2013.

http://revista.anphlac.org.br/ 
a respeito da navegação do Amazonas e das fronteiras, estavam apaziguados; terceiro - a distensão era condição necessária para evitar um novo conflito ao sul, desta vez, contra a Argentina, e para a manutenção da monarquia, o que impactaria as iniciativas continentais de integração (CERVO; BUENO, 2008, p.129-130).

Dentro do modelo, a distensão funcionaria como um impulso conservador, imprimindo uma tentativa de manter a soberania e a balança de forças. A distensão seria a face da política externa que, por força das circunstâncias, ou seja, por estar o Império voltado a si mesmo para solução dos problemas internos, teria sido a melhor saída para a manutenção da estabilidade regional e evitado uma guerra que não desejava e nem podia levar a cabo contra a Argentina.

Do outro lado, o universalismo seria a representação da perspectiva liberal em política externa para as questões internacionais. No período que compreende os anos de 1870-1889, teria se imprimido maior prestígio e extensão na ação externa, refletidas especialmente na presença, cada vez mais marcante, do Império nos congressos, feiras, foros de arbitramento internacional, viagens do Imperador e, finalmente, na aceitação em partilhar, com os Estados Unidos, das propostas panamericanistas. Se por um lado, o retraimento era necessário, em uma fase que as crises internas subtraíam as energias do país, também não era aconselhável estar fora da ampliação capitalista global. A Alemanha de Bismarck agenciava as relações internacionais europeias e se preparava com os Estados Unidos para desempenhar um papel mais ativo no cenário mundial, tornando o sistema, como um todo, mais complexo e demandando do Império decisões de circunstância. A diplomacia daqueles anos teria se aproveitado desse impulso para aumentar seus mercados e se beneficiar de forma mais intensiva do impulso cosmopolita do comércio internacional, num momento de avanço capitalista global (CERVO; BUENO, 2008, p. 129-130).

A hipótese revela que as duas tendências, distensão e universalismo, se sobreporiam e se uniriam, norteando as decisões externas no período estudado. Usando como base os axiomas apresentados, analisaremos os eventos ocorridos na política externa daqueles anos para dar ou não validade ao modelo proposto. A exposição será dividida em dois grandes eixos, sendo o primeiro com intuito de apresentar e discutir a política externa norteada pelo princípio da distensão externa e suas consequências na atuação internacional, com ênfase nos países americanos; o segundo tratando do universalismo da diplomacia Imperial, englobando as relações com o resto do mundo, em especial com os países centrais do sistema global.

\section{A distensão externa}

No dia 01 de Março de 1870, morria em Cerro Corá o ex-presidente do Paraguai, Solano López, encerrando a Guerra do Paraguai. Em toda a parte, o governo imperial declarava sua Revista Eletrônica da ANPHLAC, ISSN 1679-1061, n.15, p. 113-131, jul./dez. 2013. 
felicidade com o fim dos combates e defendia a continuidade da guerra até aquele ponto como sendo fruto do interesse nacional. O Relatório da Repartição dos Negócios Estrangeiros de 18691870, apresentando pelo então ministro barão de Cotegipe, regozijava a vitória como um triunfo da moral, exaltando a participação do Brasil e dos aliados, como sendo a de defensores de uma causa justa, da liberdade e da civilização (RRNE, 1869, p. 1-2). Na Fala do Trono, durante a abertura da Assembleia Geral em 6 de maio de 1870, D. Pedro II afirmava que a história atestaria que a geração que lutou a guerra mostrou uma constante e inabalável força para recuperar a honra nacional (FALAS DO TRONO, 1977, p. 392-393).

O Brasil, porém, pouco ganhou com a Guerra com o Paraguai, que, arruinado pelo conflito, sequer pôde pagar uma parcela da dívida de guerra (PRADO JR, 1974, p. 193). A longa e árdua campanha, em pleno processo de sua formação econômica, colocou o Império em uma situação delicada. No terreno econômico, os resultados foram nulos, já que não havia lucro possível em uma guerra contra um vizinho militarmente equipado e economicamente fraco. Do ponto de vista do desenvolvimento, o único resultado positivo da vitória brasileira foi a ocupação de pequena área de fronteira e assegurar a navegação dos rios Paraná e Paraguai, com grande importância para as comunicações com a província do Mato Grosso. O conflito também comprometeu as contas públicas, já que as grandes despesas causaram profundos desequilíbrios na vida financeira do país. Apesar da recuperação econômica após a conclusão da guerra, prova de que o Império seria naquele momento um organismo vivo em pleno crescimento, as repercussões imediatas foram agudas.

As tropas brasileiras se retiraram no dia 03 de junho de 1876, encerrando a ocupação e se tornando tema de destaque na Fala do Trono proferida pela princesa Isabel:

As forças brasileiras, que ocupavam a capital do Paraguai, recolheram-se ao Império. A disciplina, de que deram constante e apreciável testemunho, e os sacrifícios, que por anos suportaram, têm direito a que deste lugar, eu, em nome do Imperador e da nação, lhes dirija um voto de agradecimento e louvor. (FALAS DO TRONO, 1977, p. 439)

A independência, soberania e integridade territorial do Paraguai só foram totalmente asseguradas por um protocolo assinado em Montevidéu, no dia 30 de Julho de $1877^{2}$, que determinava o prazo de cinco anos, a contar da sua assinatura, para que a segurança coletiva fosse mantida (RRNE, 1877, p. 3-4). Apenas depois disso, pode-se afirmar ter havido uma verdadeira distensão da região, após décadas de intervenções no Prata. As relações na região, a partir de então, tornaram-se cada vez menos centrais para os últimos anos do Império, o que não significa que não tenham ocorrido contratempos. Apesar da escalada de tensão entre Brasil e Argentina no pós-guerra,

\footnotetext{
${ }^{2}$ Protocolo de Garantia colletiva da independência, soberania e integridade territorial do Paraguay.

Revista Eletrônica da ANPHLAC, ISSN 1679-1061, n.15, p. 113-131, jul./dez. 2013.

http://revista.anphlac.org.br/
} 
levando muitos a acreditarem numa guerra inevitável, essa possibilidade não se concretizou. No Uruguai e no Paraguai, a influência brasileira diminuiu, especialmente, pela maior presença argentina na política dos dois países.

Com a retirada das tropas de ocupação, já era possível enxergar com mais clareza também as consequências mais objetivas do conflito para o Império e seu impacto direto nos anos que se seguiram, até a queda da monarquia. Inicialmente, as perdas de aproximadamente 50 mil mortos brasileiros foram trágicas, em um país que contava com uma população de nove milhões de habitantes; desses, 139 mil participaram da guerra, ou seja, 1,5\% da população. A guerra também foi o ápice do Império e sua obra de unificação, tornando-se um fato de fortalecimento da identidade nacional a existência de um inimigo (DORATIOTO, 2002, p. 458-461).

No plano regional, os anos seguintes foram determinantes para evitar que a Argentina se apossasse de todo o Chaco, como estava determinado no Tratado da Tríplice Aliança. A preocupação brasileira sempre foi evitar o aumento da fronteira com a Argentina, obrigando o país a se aliar com o vencido, ou seja, o Paraguai, para impedir a concessão territorial argentina por direito. Apesar da presença brasileira no Prata estar enfraquecida, durante os acordos de paz entre o Paraguai e a Argentina, em 1876, os objetivos do Império foram alcançados. O território em litígio foi retomado por solução arbitral dos Estados Unidos, e a autonomia do Paraguai garantida, sendo esse último o desejo mais explícito da diplomacia imperial.

$\mathrm{Na}$ Argentina, o descontentamento do interior do país com o conflito e com a aliança com o Império contribuiu para a eclosão de várias rebeliões contra o governo central, que, ao conseguir reprimi-las, consolidou definitivamente o Estado e suas bases de legitimação. Com os presidentes Bartolomé Miltre (1862-68) e Sarmiento (1868-74), a Argentina organizava, pela primeira vez, um exército nacional e permanente, reprimindo as dissidências federalistas. O presidente Nicolás Avellada (1874-80) deflagrou a campanha para extermínio dos índios, promoveu a federalização de Buenos Aires, elevando a cidade à capital da Argentina. Com a estruturação do Estado, a rivalidade com o Brasil continuou a se acirrar, levando, em 1882, o general Julio A. Roca, então presidente da Argentina, a afirmar ser inevitável uma guerra contra o Brasil, uma guerra fatal a que ambos os países estariam destinados por contraposição de interesses e choque de civilizações, especialmente, pelo acirramento de litígios de fronteira (BANDEIRA, 2003, p. 48-51).

Se, para a Argentina, as relações internacionais platinas, durante os anos imediatos ao final do conflito com o Paraguai, constituíam-se como sendo um fracasso territorial e dos seus interesses regionais, a formação estrutural interna gerava uma década de 1880, lembrada como uma era de ouro de sua história. Com um crescimento econômico espetacular, mantido a uma taxa anual de mais ou menos cinco por cento, a Argentina impulsionou seu lugar de destaque no contexto regional Revista Eletrônica da ANPHLAC, ISSN 1679-1061, n.15, p. 113-131, jul./dez. 2013. http://revista.anphlac.org.br/ 
e até mesmo global. Sua transformação foi em grande parte resultado das mudanças que ocorreram na América e na Oceania, na corrente principal do comércio mundial. De forma geral e sintética, a Argentina se beneficiou enormemente do estabelecimento das novas rotas de comércio, da redução dos custos de transporte, do importante aumento do comércio mundial, além do movimento agudo iniciado pelo deslocamento de capital e trabalho para a periferia do sistema.

A contenda pela região de Missões foi, então, o palco do último grande embate com o Brasil durante o período imperial, apenas resolvido por laudo arbitral pelo presidente Cleveland, em 1895, portanto já República, dando ganho de causa ao Brasil. Até essa resolução, embora efetivamente os dois lados não quisessem a guerra e a corrida armamentista iniciada no período após a guerra levasse a um acirramento das tensões, só houve um recrudescimento das relações, em 7 de setembro de 1889, quando, em Buenos Aires, a negociação do tratado que iria submeter a região à resolução arbitral foi assinado.

Apesar da rivalidade com a Argentina, as relações do Império para o todo platino será de uma vigilância a distância, apenas comparecendo em caso de necessidade. Com relação ao Paraguai, a partir de 1876 até o fim da monarquia, ela deixou de ser prioritária, embora fosse extremamente importante como contrapeso à influência argentina. As relações de proximidade com o Uruguai, na mesma matriz de pensamento com relação ao Paraguai, mantiveram-se nos últimos anos do Império.

Somado aos eventos no Prata, outra questão foi fundamental para a inserção internacional brasileira nas Américas no período: os ideais americanistas de integração continental. Com a construção formal do Estado brasileiro, por meio da Constituição de 1824, e a escolha do modelo de monarquia constitucional, o Brasil representou uma variação singular dentro do sistema internacional. Sua posição passava, e isso perdurou até o final do Império, a ser sustentada externamente por se chocar com o sistema americano e com o republicanismo continental. Em uma escolha entre ser americano ou europeu, optou pela segunda opção. Dentro desse quadro constitucional, o Brasil além de destoar do resto, trazia consigo a problemática de geograficamente estar localizado em um continente que não tinha ligações profundas. A ideia de América não se coadunava com as opções adotadas pelas elites imperais, criando um abismo que permearia toda e qualquer proposta de criação de um sistema legitimamente americano:

O Império via-se civilizado e europeu, e assim de uma natureza distinta daquela de seus anárquicos vizinhos. Integrar-se a eles seria pôr em risco a própria essência de sua identidade. Se a ideia de civilização propagada pelas elites brasileiras era, estranhamente, compatível com a escravidão, a exclusão da maioria da população do corpo político da nação, a adoção do nacionalismo e da cidadania como fonte de legitimação do Estado eram potencialmente explosivas em uma sociedade fracamente integrada regionalmente e com população composta em grande parte por escravos. (SANTOS, 2004, p. 28)

Revista Eletrônica da ANPHLAC, ISSN 1679-1061, n.15, p. 113-131, jul./dez. 2013.

http://revista.anphlac.org.br/ 
Apesar de, como afirma Hélio Lobo (1939) na sua obra $O$ pan-americanismo e o Brasil, o termo pan-americanismo, lugar comum nas análises sobre integração continental, só ter sido usado pela primeira vez, nos Estados Unidos, por ocasião da Primeira Conferência Internacional Americana, a originalidade da tentativa de criação de sistema americano ressoou na política do continente durante todo o século XIX. A história dos movimentos interamericanos contou com duas vertentes originais: a norte-americana, inicialmente concebida como uma doutrina de interesse continental, encarnada na Doutrina Monroe, e o Bolivarianismo, explicitado pelas ideias de Bolívar no Congresso do Panamá. Para o Brasil, significava lidar com o ‘outro' irreconciliável, já que era o único Estado a ter no sistema dinástico sua base fundamental de legitimação nacional.

De todos os congressos interamericanos, Panamá (1826), Lima (1847-1848), Santiago (1856), Washington (1856), Lima (1864-1865) e novamente Washington (1889-1890), o Brasil somente participou do último - a Primeira Conferência Interamericana, convocada pelos Estados Unidos. O governo imperial, desde 1826, por ocasião do Congresso do Panamá, entendia que essas iniciativas poderiam ser uma fonte de resistência. Nos últimos anos do regime monárquico, norteado pela distensão, a posição do governo brasileiro se manteve em um distanciamento seguro, que resultava na ambivalência de entender que, ao mesmo tempo, as iniciativas poderiam se tornar uma frente comum contra os interesses brasileiros e também pelo receio de se ver excluído, caso algumas das iniciativas propostas alcançassem sucesso. Essa postura explica a opção por participar do Congresso de Washington, uma vez que a ambiciosa agenda de discussão aceitaria se encontrar com todo o continente pela primeira vez na mesma tribuna ${ }^{3}$.

Por fim, todos os casos destacados pelos Relatórios da Repartição dos Negócios Estrangeiros (RRNE) demonstram a inflexibilidade do governo imperial, até os últimos anos de regime monárquico, em suportar qualquer intenção mais profunda de criação de um verdadeiro interamericanismo. A distensão externa representada nas iniciativas regionais, sempre acompanhadas de uma constante vigilância para evitar qualquer coalizão antibrasileira, foi o sentido atribuído pelos formuladores da política externa e pela elite imperial, para impedir qualquer consequência que pudesse afetar a estabilidade do regime monárquico, especialmente em seus últimos anos. Essa postura só começou a mudar, quando as forças internas passaram a questionar a sua validade, ou quando um problema prático obrigava a atuar na direção contrária. Esse impulso de

\footnotetext{
${ }^{3}$ Os principais temas propostos para o Congresso foram: criação de uma união aduaneira americana; estabelecimento de comunicação regular e frequente dos portos; estabelecimento de um sistema uniforme de regulamentos sobre importação e exportação; criação de um sistema uniforme de pesos e medidas e de leis protetoras às patentes; adoção de uma moeda comum de prata, que seria emitida por cada um dos governos, com curso legal em todas as transações comerciais continentais; acordo sobre um plano definitivo de arbitragem, a fim de se resolver pacificamente os conflitos e evitar a guerra; e, por fim, considerar quaisquer outros assuntos relativos à prosperidade dos diversos Estados representados na conferência (BUENO, 2004).
}

Revista Eletrônica da ANPHLAC, ISSN 1679-1061, n.15, p. 113-131, jul./dez. 2013.

http://revista.anphlac.org.br/ 
afastamento iria contrastar vertiginosamente com os impulsos universalistas para com as potências centrais e fora do contexto regional, tema da próxima sessão.

\section{O universalismo externo}

A tendência ao universalismo tornou-se o sentido norteador da política externa imperial, por conta de uma conjuntura, na qual o retraimento não era aconselhável, segundo hipótese levantada por Amado Luiz Cervo (2008). A maior dessas alterações aconteceu no começo da década de 1870, quando teve início o sistema europeu de alianças, criado por Otto von Bismarck. Ainda que a pentarquia do Concerto Europeu ${ }^{4}$, fundado em 1815, pelo Congresso de Viena, para conter os efeitos da Revolução Francesa, fosse a característica essencial do sistema político europeu, o equilíbrio de poder tornou-se diferente nos anos 1870-1889. A França experimentou uma fase de introspecção, após a derrota na guerra Franco-Prussiana, tentando, de alguma forma, restaurar seu prestígio internacional abalado pela derrota. A Grã-Bretanha, que desde o final das Guerras Napoleônicas dominava a economia global, passava a conhecer um incômodo pluralismo econômico, oriundo das outras potências industriais, vendo-se forçada a repensar a sua política de isolamento dos assuntos continentais. A Áustria e a Rússia, pela nova conjuntura, passaram a desempenhar um papel menor daquele que vinham assumindo até então.

Dessa forma, o arranjo central das forças europeias se centrou na Alemanha, que, apesar de possuir potencial econômico e militar suficientemente poderoso para romper com toda a lógica dos poderes consagrados desde Viena, optou por uma postura cautelosa, protegendo a recém-unificação e neutralizando a possibilidade de um revanchismo francês (LESSA, 2008, p. 131-133). A construção vitoriosa do Segundo Reich constituiu o evento mais importante do último quartel do século XIX, e a influência da sua presença e do seu chanceler Bismarck foi tão grande, que é possível falar em um sistema bismarckiano, no período compreendido entre 1870-1890.

Esse sistema durou até 18 de março de 1890, quando o "Chanceler de Ferro" se indispôs com o herdeiro do trono alemão, por problemas de política interna, e renunciou ao posto. Durante

\footnotetext{
${ }^{4}$ O Concerto Europeu, iniciado pelos Acordos de Viena (1814-1815), puseram fim a um quarto de século de levantes e de guerras, trazendo novo equilíbrio para o sistema europeu. O mapa da Europa foi redefinido, sem se levar em conta as aspirações dos povos ou qualquer direito dos inúmeros príncipes destituídos pelos franceses, mas com considerável atenção ao equilíbrio dos cinco grandes: a Rússia, a Grã-Bretanha, a França, a Áustria e a Prússia. A declaração das cinco potências foi formalizada em 1818, pela Declaração de Aachen (Aquisgrana), em que afirmavam sua intenção de manter uma união íntima de consultas regulares para a preservação da paz. (WATSON, 2004, p. 334-335) Segundo Hobsbawn (2007, p.168-172), “Os reis e estadistas não eram mais sábios nem tampouco mais pacíficos do que antes. Mas inquestionavelmente estavam mais assustados”, e talvez, por isso, eles tenham sido inusitadamente tão bemsucedidos. De fato, não houve nenhuma guerra total na Europa, nem qualquer conflito armado entre duas grandes potências, da derrota de Napoleão à Guerra da Crimeia (1854-1856). Além disso, com exceção dessa, não houve nenhuma guerra que envolvesse mais do que duas grandes potências entre 1815 e a Primeira Guerra Mundial.
}

Revista Eletrônica da ANPHLAC, ISSN 1679-1061, n.15, p. 113-131, jul./dez. 2013. http://revista.anphlac.org.br/ 
todo o período, conseguiu transformar as relações internacionais europeias em um sistema que girava em torno da Alemanha. Para o sistema mundial, que dependia e tinha relações diretas com a Europa, era uma nova porta na relação com os países centrais. O sistema europeu conviveria com uma nova multipolaridade, muito mais aguda do que aquela experimentada, durante todo o século XIX até então, especialmente, pela emergência de novas potências e o declínio de outras, dando uma dinâmica original ao sistema.

A economia do período foi marcada por uma longa recessão na Europa e uma mudança paulatina no poder mundial. Ainda que os ritmos das correntes de comércio se mantivessem crescendo, a produtividade aumentava de forma abrupta, gerando um grande descompasso entre a oferta e a demanda, o que afetava diretamente os preços. As relações econômicas se mundializaram, transformando as realidades locais por meio do capital dos países centrais, cada vez mais pulverizados ao redor do planeta. Os fluxos financeiros alcançaram níveis inéditos, especialmente pela velocidade de transformação das novas tecnologias.

Voltada para a produção de produtos primários e de exportação, a América Latina passou por sérias mudanças, por conta das alterações no sistema capitalista global. Após décadas de crises internas, os países da região começavam a respirar a consolidação do projeto econômico-político das suas elites. A aceitação, de forma quase incondicional, de sua posição na divisão internacional do trabalho trouxe um avanço rápido no crescimento material e um período de esplendor, consolidação política e dos arcabouços institucionais, só possíveis nessa nova conjuntura (MALAMUD, 2005, p.327). Em muitos casos, o crescimento econômico se deu num ambiente de representatividade política, quase sempre com o Parlamento em seu pleno funcionamento, dando ao período a sua versão latino-americana da belle époque. A presença europeia na região se fez sentir, na economia, com a circulação de capitais, tecnologias e produtos; no campo social, pela chegada massiva de imigrantes europeus em vários países sul-americanos; e, finalmente, em termos políticos, por pressão dos acordos comerciais, essenciais às potências europeias na disputa por novos mercados.

Nesse complexo sistema internacional, estava inserido o Brasil, composto por uma sociedade de base agrária, um regime político de tipo monárquico, que ainda fazia uso da mão de obra escrava na sua estrutura de produção e estava inserido em uma lógica global e, especialmente, regional, muito díspar daquela que se fazia presente no país. A nova ordem internacional que vinha se consolidando, desde a metade do século XIX, foi o desafio essencial para os formuladores de política externa do Império do Brasil. O Império se esforçava para manter a intensidade dos vínculos políticos e econômicos, mantidos pelo país com o resto do mundo, especialmente com o centro do sistema capitalista, saindo de um bilateralismo para um universo crescente de Revista Eletrônica da ANPHLAC, ISSN 1679-1061, n.15, p. 113-131, jul./dez. 2013.

http://revista.anphlac.org.br/ 
multilateralismo, sendo essa uma tendência até o final da monarquia (ALMEIDA, 2001, p. 375381).

Em 1851, a Exposição Universal do Crystal Palace, em Londres, realizada pela "iniciativa privada", dava início a uma sucessão de conferências, congressos, seminários científicos e industriais. Era nessas reuniões, com múltiplos objetivos, normalmente vinculados a algum assunto “técnico", que se ressaltavam a maior participação de atores no jogo da política mundial, denotando uma amplitude universalista nas relações internacionais. Os convites foram usuais em toda a década de 1870 e, especialmente, de 1880. Os Relatórios do Ministério dos Negócios Estrangeiros contêm uma infinidade de convites ao Brasil, solicitado para quase todos os assuntos consideráveis do período, entre eles: convenções postais, união postal, acordos referentes aos mares, convenção telegráfica, acordos de proteção industrial e de marca, exposições internacionais etc.

No comércio internacional, a alteração na matriz das exportações do Império determinou a reorientação geográfica do destino dos produtos brasileiros, especialmente a Grã-Bretanha, mercado modesto para o essencial café, perdendo importância principalmente para os Estados Unidos, mas também para países da Europa continental, marcando assim um universalismo também na atuação econômica externa (ABREU; LAGO, 2010, p. 24).

O café foi um dos responsáveis por essa atuação e objeto fundamental na tentativa universalista da política externa brasileira. Com sua cultura totalmente adaptada ao solo do sudeste do Brasil e com o fácil escoamento da produção e armazenagem, a mercadoria era o mais bemsucedido produto brasileiro no comércio internacional, no período final do Império. Na década de 1870, foram introduzidos vários tipos de despolpadores mecânicos e aperfeiçoadas as técnicas de torrefação. Na de 1880, uma praga assolou os concorrentes asiáticos do café brasileiro, fazendo com que a conjuntura favorável expandisse rapidamente as plantações. Se durante a década de 1830, as exportações de café eram de aproximadamente 60.000 toneladas anuais; em 1871, o Brasil exportaria 216.000 toneladas, chegando até os últimos anos do Império na casa das 888.000 toneladas (DEAN, 2008, p. 669-670).

A partir de 1873, o café brasileiro teve assegurada a livre entrada no mercado americano, com a política republicana do "free breakfast table”. No final dos 1880, o Brasil era responsável por aproximadamente $70 \%$ do total de importações de café nos Estados Unidos, o que contrastava com a Europa, onde o café era pesadamente taxado por impostos de importação ou sobre consumo. As exportações para a Grã-Bretanha caíram de forma vertiginosa, enquanto para os Estados Unidos tendiam a ultrapassar $40 \%$ do total. A mudança da estrutura de origem das importações no período imperial também refletiu a mudança das posições dos países centrais no sistema capitalista global. O declínio da capacidade competitiva das importações britânicas fez com que a Grã-Bretanha fosse Revista Eletrônica da ANPHLAC, ISSN 1679-1061, n.15, p. 113-131, jul./dez. 2013. 
paulatinamente substituída por produtores concorrentes, especialmente a Alemanha e os Estados Unidos. O Brasil dependia quase exclusivamente das importações, para o suprimento de um amplo leque de bens manufaturados. Em meados dos 1870, "artefatos de algodão" correspondiam a 27,5\% das importações, bebidas a $18 \%$, peixes a $10 \%$, "artefatos de lã" a $6,6 \%$, trigo e farinha de trigo a $5 \%$ e carvão a 3,9\%. Máquinas respondiam por apenas $1,7 \%$ do total, embora sua importância tenha talvez dobrado na década de 1880 (ABREU; LAGO, 2010, p. 24).

As relações do Império, cada vez mais abrangentes, eram mais uma demonstração do universalismo na esfera internacional. Na Europa, as relações do Império com a Alemanha, especialmente as comerciais, provavam o caráter multifacetado do sistema que emergiu nas décadas de 1870 e 1880. Se, culturalmente, a preferência das elites imperiais sempre foi pela França, e, politicamente, as relações mais estreitas eram para com a Inglaterra, a Alemanha despontava naqueles anos como um competidor à altura do desafio. O Brasil parecia, naqueles anos também, estar disposto a ampliar seu intercâmbio com outros polos de poder e, dentro das possibilidades, escaparem à alternativa britânica. A Alemanha, empenhando-se na concorrência com a Inglaterra, logo após o conflito contra a França, fez do Império brasileiro mais um dos cenários em que se desenrolaria o conflito econômico das grandes potências (CAMPOS, 2004, p. 253-254).

As relações foram amistosas entre o governo imperial e os franceses nos últimos anos da monarquia, salvo os pequenos problemas durante a Guerra Franco-Prussiana e algumas questões de limites. Do ponto de vista das relações culturais, a influência francesa foi sentida durante todo o século XIX (BOSI, 2012, p. 227-228). Na elite imperial, as representações externas, dominante em todos os aspectos da vida social e cultural, pertenciam à França. A literatura consumida no país, artigo de luxo em uma sociedade, composta de uma pequena aristocracia cercada por analfabetos, era prioritariamente francesa, sendo que mesmo os romances ingleses eram traduções francesas. Com exceção de Darwin e Spencer, os pensadores franceses como Auguste Comte, Ernest Renan Arthur, o conde de Gobineau predominavam na vida intelectual do Império na fase final do Império. Apenas a ópera italiana era mais apreciada do que as francesas nos teatros cariocas e de outras cidades brasileiras. Na moda, as tendências francesas eram as mais procuradas na rua do Ouvidor, no centro do Rio de Janeiro (BETHELL, 2012, p. 153).

Grandes políticos, letrados e até o imperador tinham grande fascínio pela representatividade da França na história e, em especial, de Paris. Joaquim Nabuco, apesar da sua notória preferência por Londres, afirmava ser quase impossível chegar pela primeira vez em Paris e ficar indiferente ao maravilhoso, que surpreendia a cada passo. Independente do seu gosto pessoal, reconhecia que "Paris foi e é a paixão cosmopolita em redor de nós" (NABUCO, 1963, p. 50-84).

Revista Eletrônica da ANPHLAC, ISSN 1679-1061, n.15, p. 113-131, jul./dez. 2013. http://revista.anphlac.org.br/ 
Nas trocas comerciais, como não poderia deixar de ser, através dos anos, a supremacia das importações francesas eram de artigos que vestiam e alimentavam o brasileiro, além de itens para uso doméstico e das estruturas de produção aqui residentes. As mercadorias variavam, com predominância de manufaturas e tecidos, além de vinhos, manteiga, vestuários e produtos industrializados em geral. As exportações acompanhavam o resto das operações com as potências centrais, com grande primazia do café, conquistando, em alguns exercícios fiscais, inclusive superávit nas relações comerciais (DEVEZA, 2004, p. 198-200).

As relações com a Grã-Bretanha foram cordiais, especialmente após a extinção do tráfico negreiro, o reatamento das relações diplomáticas após o término da Questão Christie (1862-1865) e o apaziguamento do Prata. As questões econômicas, em especial, comércio e investimentos, eram, sem dúvidas, as matérias essenciais entre os dois países naqueles anos. Não que se pode ignorar as esferas de influência cultural, especialmente nos núcleos da intelectualidade brasileira, entre eles Rui Barbosa e Joaquim Nabuco, esse último, confesso apaixonado pelos ingleses e grande apreciador das suas instituições.

De qualquer maneira, porém, é incontestável terem sido os interesses britânicos no Império de ordem acentuadamente econômico, incluindo nesse contexto a questão da escravidão, tão cara à diplomacia dos ingleses. A Lei do Ventre-Livre, em 1871, muito deve à pressão britânica, trazendo com ela uma das mais acirradas controvérsias entre o Brasil e a Inglaterra. O Império sempre lidou de forma extremamente dual em relação às requisições inglesas: era usual os britânicos fazerem exigências exorbitantes, e, em geral, a diplomacia do Império respondia verbal e publicamente, manifestando suas intenções de satisfazer aos pedidos; por outro lado, usava do expediente de adiar, procrastinar e tornava insignificante grande parte do objetivo dos britânicos. A situação só mudava, quando as demandas internas se somavam aos pedidos britânicos, ou quando o governo imperial entendia ser necessário, de fato, tomar uma determinada posição, momento em que cedia aos britânicos (GRAHAM, 2004, p.168-172).

As relações econômicas da Grã-Bretanha com o Brasil, e não apenas com ele, mas com toda a América Latina durante os anos de 1870 e de 1880, representavam uma época de ouro dos países da região, especialmente, pelo salto exponencial dos setores da economia baseados na exportação. Essa explosão se deu, principalmente, pelo aumento da demanda (inclusive inglesa) de gêneros alimentícios e matérias-primas, que só foi possível pela revolução comandada pelos ingleses nas comunicações e nos transportes, além da maciça entrada de capitais daquele país. $\mathrm{O}$ tamanho dos investimentos estrangeiros na América Latina é difícil de mensurar, porém, há algum consenso de que o investimento britânico era de ao menos 200 milhões de libras em 1880, sendo quase um quarto no Brasil. Usualmente, as elites viam com muito bons olhos a penetração do Revista Eletrônica da ANPHLAC, ISSN 1679-1061, n.15, p. 113-131, jul./dez. 2013. http://revista.anphlac.org.br/ 
capital britânico, recebendo daquela fonte os benefícios da modernização capitalista (BETHELL, 2009, p. 582-598).

Por fim, nenhum assunto ocupou maior atenção dos homens do Império, naqueles últimos anos de regime monárquico, do que o sistema servil. A escravidão era a contradição mais essencial da sociedade brasileira, uma vez que a sua autoimagem, projetada pelas velhas elites, especialmente sobre os vizinhos, traziam no Império a ideia de civilização e luzes. O fim da Guerra do Paraguai trouxe uma nova fase nas questões abolicionistas e sua luta contra o cancro que roía as entranhas da sociedade brasileira, como bem definiu José Bonifácio (CARVALHO, 2007, p. 130).

Para a diplomacia, era grande o desafio, uma vez que a contestação da opinião pública, cada vez mais mundanizada, e as pressões externas originadas especialmente pela Inglaterra e, no final da década de 1880, da Santa Sé. Incapaz de evitar as consequências da manutenção da escravidão, coube então à diplomacia o papel, naquelas duas décadas, de potencializar qualquer avanço rumo à abolição e, ao mesmo tempo, trabalhar para garantir que não faltasse mão de obra.

Em 1880, ao custo de 120 contos de réis, especialmente alocados na ocasião, decidiu-se enviar uma missão diplomática especial à China, com o controvertido objetivo de procurar mão de obra chinesa para a lavoura (ALMEIDA, 2001, p. 364). A oposição à imigração chinesa contava com algumas das maiores inteligências da época, que souberam combatê-la com grande veemência, dissuadindo as diversas vozes no confronto de ideias do Parlamento. Os argumentos eram de várias naturezas: políticos, econômicos, históricos, biológicos e até mesmo racistas (CERVO, 1981, p. 178-180).

O tratado foi promulgado pelo decreto $\mathrm{n}^{\circ} 8.651$ de 24 de agosto de 1882 , com cláusulas típicas do período e extremamente semelhante àqueles que as potências imperialistas impunham a diversos Estados ao redor do mundo. Ainda assim, a imigração pretendida não foi alcançada, sendo considerada a missão um total fracasso para uma parcela dos deputados. Não se pode atribuir total fracasso à missão brasileira na China, uma vez que a resistência se deu por conta dos líderes chineses, que, sensibilizados com as campanhas de difamação contra os imigrantes chineses, tomou a defesa de seus súditos e não aceitou o acordo, além de ter conseguido garantir a abertura dos portos brasileiros ao comércio e a imigração voluntária de seus conterrâneos (CERVO, 1981, p.184187). A imigração chinesa foi apenas esporádica nos momentos derradeiros do Império, ainda que as imigrações europeias, especialmente portuguesas, italianas e alemãs tenham aumentado substancialmente. No entanto, o caso da China mostra a abrangência alcançada pelo universalismo do período.

\footnotetext{
${ }^{5}$ Tratado de Amizade, Commercio e Navegação celebrado entre o Brazil e a China em 03/10/1881 - Promulgado 24/06/1882, RRNE, 1882, Anexo I, p. 41-52

Revista Eletrônica da ANPHLAC, ISSN 1679-1061, n.15, p. 113-131, jul./dez. 2013.

http://revista.anphlac.org.br/
} 
O Império participou também das mais importantes realizações do período, em especial as grandes exposições universais. Em 1876, milhões de visitantes foram à Feira da Filadélfia, para conhecer a invenção do telefone, entre eles o próprio imperador, em uma das suas visitas internacionais, que, junto ao presidente americano Grant inaugurou a exposição, em plena euforia do centenário da independência dos Estados Unidos. Na feira de Paris, em 1889, onde foi inaugurada a Torre Eiffel, o Brasil foi representado em um grande pavilhão, próximo à torre. A importância desses eventos revelava-se na promoção comercial e no aumento do prestígio do Império, fazendo com que sua participação mostrasse o Brasil ao resto do mundo. Originalmente concebida em formato nacional, no intuito de comemorar o centenário da Revolução Francesa, a Exposição Internacional de Paris foi fortemente criticada pelos monarquistas e passou a sofrer boicote das principais casas reais da Europa. O Império brasileiro, que havia, por um decreto de 1888, autorizado a criação de uma comissão para o evento, com um gasto de até 300 contos de réis, chegou a hesitar quanto a sua participação, mas, com restrições orçamentárias, o Brasil, a última monarquia da América, aceitou participar da exposição (ALMEIDA, 2001, p.240-242).

Para isso, a comissão brasileira preparou uma grande obra de apresentação do Brasil, Le Brésil en 1889, além de um pavilhão em três andares de ferro e vidro, inaugurado em 14 de junho de 1889, projetado pelo renomado arquiteto francês Louis Dauvergue, ocupando 1.2 mil metros quadrados, em ótima localização, perto da Torre Eiffel, mostrando um país progressista, recémemancipado do escravismo, em pleno desenvolvimento econômico e moderno. O sucesso e a impressão positiva foram grandes, a ponto de ter ocorrido uma verdadeira consternação da opinião pública francesa com a queda da monarquia, já nos momentos finais da exposição da capital parisiense.

A razão dessa comoção em relação à derrubada da monarquia pode ser parcialmente explicada pela figura de D. Pedro II e suas viagens internacionais no período de 1870-1889. O imperador realizou três longas viagens nas décadas de 1870 e 1880, com grande repercussão interna pelos lugares de seu destino. A discussão sobre o assunto é vasta, uma vez que o real impacto dessas viagens para o prestígio nacional ainda não é totalmente consensual e perpassa inclusive a própria estrutura constitucional imperial.

Inicialmente, a adoção do regime monárquico alçou o país a um modelo que não identificava paralelos com seus vizinhos. Sua posição passava, e isso perduraria até o final do império, a ser sustentada externamente, por se chocar ao sistema americano e ao republicanismo continental. A escolha pela opção europeia de regime político orientava as ações do Império brasileiro. A relação da Casa Imperial com as monarquias europeias era fator de grande relevância para o próprio imperador e para a posição do país nas redes de interesses internacionais.

Revista Eletrônica da ANPHLAC, ISSN 1679-1061, n.15, p. 113-131, jul./dez. 2013.

http://revista.anphlac.org.br/ 
A política externa em todas as suas faces é por definição a atribuição mais essencial da figura do chefe de Estado. Nele, reside a personificação da Nação e, portanto, sua face externa. No caso de um regime monárquico, como era o brasileiro, o imperador era a personificação do Brasil, estando dentro ou fora do Império, na situação que fosse. Apesar de absolutamente óbvio que a passagem do imperador do Brasil, por onde quer que ele fosse, tivesse causado grande mobilização, para não dizer comoção, torna-se difícil avaliar se as viagens do Imperador realmente foram um instrumento para elevar o prestígio imperial, ou meramente viagens particulares, de um imperador cansado e entediado pelos longos anos de atividade política.

As opiniões se dividem em relação à importância das viagens e suas consequências práticas. Amado Luiz Cervo e Clodoaldo Bueno (2002), por exemplo, atribuem grande relevância para o Império e sua visão externa:

\begin{abstract}
Empreendeu três importantes viagens pelo Ocidente (1871, 1875 e 1887), durante as quais estabeleceu contatos de alto nível com governos e instituições dos Estados Unidos, de quase todos os países europeus, incluindo a Rússia dos czares, o Império Otomano, a Grécia, a Terra Santa e o Egito. O chefe do Estado brasileiro tornava assim o país mais conhecido e respeitado no exterior. (p.135-136)
\end{abstract}

Usando das prerrogativas de um chefe de Estado, que tinha ligações com várias casas reinantes europeias e que era monarca do maior país da América do Sul, o imperador conseguiu acesso natural aos mais restritos meios políticos e culturais, que renderam ganhos na promoção da sua autoimagem e, por consequência, na imagem do Império no exterior.

As grandes problemáticas das viagens foram as acusações de uma possível falta de conteúdo diplomático e a reação desfavorável que produziram nos meios políticos, na imprensa e na opinião pública do Império. Os críticos afirmavam que as visitas eram apenas particulares e com pouca profundidade nos contatos mantidos, além das dúvidas suscitadas quanto ao real interesse que teria levado D. Pedro II a decidir por elas. O caráter ambíguo das viagens era, inclusive, reiterado pelos meios oficiais. No Relatório da Repartição dos Negócios Estrangeiros de 1881, afirmava que:

Com maior jubilo vos communico que a presença de Sua Magestade o Imperador e de sua Augusta Consorte na Europa, foi saudada por modo summamente lisongeiro a nação brazileira. Apezar de viajarem como simples particulares, forao Suas Majestades acolhidos em todos os paízes que visitárão com demonstrações de especial symphatia e consideração. (p.1-2)

Após grandes discussões no Parlamento, uma vez que, o art. $104^{6}$ da Constituição do Império, obrigava-o a liberar o imperador, para que a sua ausência não configurasse abdicação do

\footnotetext{
6 “Art. 104. O Imperador não poderá sahir do Imperio do Brazil, sem o consentimento da Assembléa Geral; e se o fizer, se entenderá, que abdicou a Corôa" (Constituição Política do Império do Brasil de 25 de março de 1824).

Revista Eletrônica da ANPHLAC, ISSN 1679-1061, n.15, p. 113-131, jul./dez. 2013.

http://revista.anphlac.org.br/
} 
trono, o imperador embarcou para a primeira das visitas, mesmo sob gritos da oposição, especialmente pelo momento político sério em que o país estava imerso, com o término da Guerra do Paraguai. O imperador, confiante que o Gabinete Rio Branco equilibraria o quadro de inquietações políticas, não hesitou em fazer a primeira viagem, ainda mais quando recebeu a notícia do falecimento de sua filha, Princesa Leopoldina, duquesa de Saxe (GOUVÊA, 1978, p. 107-108).

Do dia 25 de maio de 1871 a 30 de março de 1872, visitou Portugal, Espanha, França, Inglaterra, Bélgica, Alemanha, Itália, Ásia Menor e Palestina. Durante o percurso, encontrou-se com diversas personalidades do mundo político e acadêmico-intelectual como: Thiers, a rainha Vitória, o rei Leopoldo, Guilherme I, Francisco José I da Áustria, Vitor Emanuel, papa Pio IX, Leão XIII, Gladstone, Alexandre Herculano, Gobineau, Richard Wagner e Camilo Castelo Branco (DANESE, 1999, p. 246).

A segunda viagem se estendeu do dia 26 de março de 1876 a 26 de setembro de 1877, após ter visitado os Estados Unidos - no momento histórico do primeiro monarca coroado ao país -, ao Canadá, Alemanha, Suécia, Finlândia, Rússia, Áustria, França, Inglaterra, Escócia, Irlanda, Holanda, Suíça e Portugal. O trecho relativo aos Estados Unidos tornou-se o mais conhecido, pois não só percorreu várias cidades do país, mas acompanhou o presidente Grant na Exposição da Filadélfia, por ocasião do centenário da independência americana:

E, para realçar o significado histórico do dia, o Imperador do Brasil mostrará, pela sua presença, a amizade do Brasil ao nosso povo e o interesse pela feira internacional. O caráter americano da Exposição do Centenário sobreleva no fato notável de que os governantes das suas grandes nações americanas tomarão parte na solenidade. (GUIMARÃES, 1961, p. 225)

Essa viagem foi dedicada a contatos sociais, oficiais e com grandes acadêmicos e cientistas. Nos Estados Unidos, conheceu Alexander Bell e falou ao seu invento, o telefone, a sensação da exposição; encontrou o filósofo Emerson e os poetas John Whittier e Longfellow. Na Europa, reencontrou Gobineau, que foi guia de parte da viagem do imperador na sua segunda passagem pelo continente. Encontrou por duas vezes Victor Hugo e Alexandre Herculano, além de visitar Guilherme I, o czar Alexandre II e o papa Pio IX. Por fim, na sua terceira viagem, dessa vez com fins médicos, ficou fora do Império entre 30 de junho de 1887 a 22 de agosto de 1888, visitando Portugal, França, Alemanha, Bélgica e Itália (DANESE, 1999, p. 246-247).

Pouco depois, cairia a monarquia brasileira, mas, com poucas exceções, a impressão geral deixada pelo imperador ao mundo não criou grande comoção sobre a adoção do regime republicano. O poliglota soberano, Bragança e Habsburgo, com livre circulação entre os círculos mais restritos 
dos países 'civilizados', deixou por onde passou a melhor das impressões, transparecendo uma visão modernizadora do exótico reino do Atlântico Sul, sendo a melhor metáfora da face universalista dos anos finais do Império.

\section{Considerações Finais}

As duas tendências, distensão e universalismo, se sobrepunham e se uniam para formar o grande periscópio das relações internacionais do Império no período de 1870-1889. O Império sofreu constante influência conjuntural, o que, conscientemente ou não, para os formuladores de sua política internacional, impulsionou as duas forças de forma contínua. Aparentemente antagônicas, as duas acabam por revelar a metáfora de um período de graves conflitos internos e desafios crescentes, especialmente com o avanço do capitalismo em escala global. Ainda que de forma reativa, na maioria dos casos, o período foi marcado pela defesa do interesse nacional e da tentativa de uma inserção dentre as possibilidades sistêmicas.

No Prata, a política para a região seria norteada pela distensão externa, nos moldes apresentados anteriormente neste estudo, apesar de essa configuração só poder ser vista em todos os seus contornos, após a retirada das tropas brasileiras de Assunção, em 1876. Algo muito semelhante com o ocorrido nas tentativas interamericanistas, que presenciaram, durante todo o período, a reprodução da tendência histórica do Império de resistência às iniciativas de integração com o resto do mundo; a explosão do multilateralismo, após a adoção do sistema bismarckiano na política continental europeia; a pauta ampla de assuntos com as principais potências capitalistas; e a mudança nos fluxos de comércio internacional dos produtos brasileiros, especialmente o café, foram fundamentais para reforçar o universalismo.

A abertura de novos mercados ajudou a consolidar a dominação da elite agroexportadora também pela política externa, transformando-se em um dos elementos primordiais de inserção internacional. Um dos caminhos para isso foi a participação em todos as conferências, congressos, seminários científicos e industriais possíveis, como meio de usar do prestígio desses eventos como motor propulsor do aumento das exportações.

A experiência global do período obrigava o Império, o imperador e todos os formuladores de política externa a expandirem as relações em níveis até então inéditos, denotando claramente a vertente universalista como sentido da condução dos assuntos externos. Isso ficaria claro no uso ostensivo da esfera internacional na solução de graves problemas internos, inclusive alguns deles responsáveis diretos pela queda do regime, como a questão servil; e na procura pelo prestígio externo, simbolizado nas viagens de D. Pedro II. As duas tendências, portanto, foram fundamentais

Revista Eletrônica da ANPHLAC, ISSN 1679-1061, n.15, p. 113-131, jul./dez. 2013.

http://revista.anphlac.org.br/ 
para dar inteligibilidade ao período e se apoiam com maior ou menor assertividade nos eventos mencionados do período.

\section{Referências Documentais}

COSNTITUIÇÃO Política do Império do Brasil (de 25 de março de 1824): Disponível em <http://Www.planalto.gov.br/ccivil_03/constituicao/constituiçao24.htm>. Acesso em: 12/12/2012.

FALAS DO TRONO. São Paulo: Companhia Melhoramentos, 1977.

RELATÓRIOS DA REPARTIÇÃO DOS NEGÓCIOS ESTRANGEIROS (RRNE) 1865/1890.

\section{Referências Bibliográficas}

ABREU, Marcelo de Paiva; LAGO, Luiz Aranha Correa do. A economia brasileira no Império, 1822-1889. No. 584. 2010. Disponível em: 〈http://www.econ.puc-rio.br/pdf/td584.pdf〉. Acesso em: $24 / 11 / 2013$.

ALMEIDA, Paulo Roberto de. Formação da diplomacia econômica no Brasil: as relações econômicas internacionais do Império. São Paulo: Editora Senac-Funag. 2001.

BANDEIRA, Luiz A. Moniz. Conflito e integração na América do Sul (Da Tríplice Aliança ao Mercosul 1870-2003). 2a ed. Rio de Janeiro: Revan, 2003.

Presença dos Estados Unidos no Brasil (dois séculos de história).

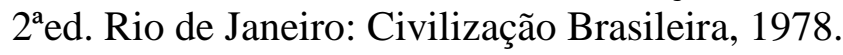

BETHELL, Leslie. O Brasil e a ideia de “América Latina” em perspectiva histórica. In. Estudos Históricos,v.22, n.44, p. 289-321, julho-dezembro de 2009. Disponível em: <http://www.scielo.br/pdf/eh/v22n44/v22n44a01.pdf>. Acesso em: 12/01/2012.

. O Brasil no mundo. In: CARVALHO, José Murilo de (Coord.). A construção nacional (1830-1889). Rio de Janeiro: Objetiva, 2012. Volume 2. p.131-177.

; CARVALHO, José Murilo de Carvalho. O Brasil da independência a meados do século XIX. In: BETHELL, Leslie. História da América Latina: volume III: Da Independência Até 1870. São Paulo: Editoria da Universidade de São Paulo; Imprensa Oficial do Estado; Brasília: Fundação Alexandre de Gusmão, 2001. p. 695-770.

BOSI, Alfredo. Cultura. In: CARVALHO, José Murilo de (Coord.). A construção nacional (18301889). Rio de Janeiro: Objetiva, 2012. Volume 2. p. 225-279

CALMON, Pedro. História da civilização brasileira. Brasília : Senado Federal; Conselho Editorial, 2002.

CALÓGERAS, Pandiá. A política exterior do Império. Brasília: Fundação Alexandre Gusmão; Companhia Editora Nacional Brasiliana; Câmara dos Deputados, 1989.

Exército, 1957.

Formação histórica do Brasil. $5^{\mathrm{a}}$ ed. Rio de Janeiro: Biblioteca do

CAMPOS, Pedro Moacyr. Brasil - Alemanha. In: HOLANDA, Sérgio Buarque de (Dir.). História geral da civilização brasileira. 6 $^{\mathrm{a}}$ ed. Rio de Janeiro: Bertrand Brasil, 2004. Volume 6. p. 253-271

CARVALHO, Delgado de. História diplomática do Brasil. São Paulo: Editora Nacional, 1959.

Revista Eletrônica da ANPHLAC, ISSN 1679-1061, n.15, p. 113-131, jul./dez. 2013.

http://revista.anphlac.org.br/ 
CARVAlHO, José Murilo de. D. Pedro II: ser ou não ser. $2^{\mathrm{a}}$ ed. São Paulo: Companhia das Letras, 2007.

CASTRO, Flávio Mendes de Oliveira. Dois séculos de história da organização do Itamaraty (18082008). Brasília: Fundação Alexandre de Gusmão, 2009.

BUENO, Clodoaldo. Panamericanismo e projetos de integração: temas recorrentes na história das relações hemisféricas (1826-2003). In. Política Externa, v. 13, nº 1, p. 65-80, 2004.

; CERVO, Amado Luiz. História da política exterior do Brasil. $3^{\mathrm{a}}$ ed. Brasília:

Editora Universidade de Brasília, 2008.

CERVO, Amado Luiz. Inserção Internacional: formação dos conceitos brasileiros. São Paulo: Saraiva, 2008.

Universidade de Brasília, 1981.

O parlamento brasileiro e as relações exteriores (1826-1889). Brasília: Ed.

CHACON, Vamireh. História dos partidos brasileiros: discurso e práxis dos seus programas. Brasília:, Editoria Universidade de Brasília, 1981.

COSTA, Emília Viotti da. Da monarquia à república: momentos decisivos. São Paulo, Brasiliense, 1987.

DANESE, Sérgio. Diplomacia presidencial. São Paulo: TopBooks, 1999.

DEVEZA, Guilherme. Brasil-França. In: HOLANDA, Sérgio Buarque de (Dir.). História geral da civilização brasileira. $6^{\text {a }}$ ed. Rio de Janeiro: Bertrand Brasil, 2004. p. 181-201.

DORATIOTO, Francisco. Maldita guerra: nova história da Guerra do Paraguai. São Paulo: Companhia das Letras, 2002,

DORATIOTO, Francisco. O Império do Brasil e as grandes potências. In: MARTINS, Estevão Chaves de Rezende (Org.). Relações internacionais, visões do Brasil e da América Latina. Brasília: IBRI/Funag, 2003. p. 133-151

GOUVÊA, Fernando da Cruz. O imperador itinerante. Recife: Governo do Estado de Pernambuco; Secretaria de Educação e Cultura, 1978.

GRAHAM, Richard. Brasil. Inglaterra. HOLANDA, Sérgio Buarque de (Dir.). História geral da civilização brasileira. $6^{a}$ ed. Rio de Janeiro: Bertrand Brasil, 2004. p.167-180.

Constructing a nation in nineteenth-century Brazil: old and new views on class, culture, and the State. In: The Journal of the Historical Society, v. 1, n. 2-3, p. 17-56, 2001. Disponível em:

<http://www.dhi.uem.br/publicacoesdhi/dialogos/volume01/vol5_mesa1.html\#_edn1>. Acesso em: $12 / 12 / 2011$.

GUIMARÃES, Argeu. D. Pedro nos Estados Unidos: as reportagens de James O’ Kelly e o diário do imperador. Rio de Janeiro: Civilização Brasileira, 1961.

HOBSBAWM, E. J. A era dos extremos: o breve século XX, 1914-1989. São Paulo, Companhia das Letras, 2007.

LESSA, A. C. História das relações internacionais: a Pax Britannica e o mundo do século XIX. $3^{\text {a }}$ ed. Petrópolis: Vozes, 2008.

LOBO, H. O pan-americanismo e o Brasil. São Paulo: Editora Nacional, 1939.

MALAMUD, C. Historia de America. Madri: Alianza Editorial, 2005.

Revista Eletrônica da ANPHLAC, ISSN 1679-1061, n.15, p. 113-131, jul./dez. 2013.

http://revista.anphlac.org.br/ 
NABUCO, Joaquim. Joaquim Nabuco. Diários (1873-1910). 2a ed. Rio de Janeiro: Bem-Te-Vi:, 2005. . Minha formação. Brasília: Editora Universidade de Brasília, 1963.

PRADO JÚNIOR, Caio. História econômica do Brasil. São Paulo: Brasiliense, 1974.

SANTOS, L. C. V. O Brasil entre a América e a Europa. O Império e o interamericanismo (do Congresso do Panamá à Conferência de Washington). São Paulo: Editora UNESP, 2004.

WATSON, A. A evolução da sociedade internacional: uma análise histórica comparativa. Brasília: Editora Universidade de Brasília, 2004. 